\title{
FACTORS AFFECTING THE USE OF PERSONAL PROTECTIVE EQUIPMENT AMONG TOBACCO FARMERS: APPLICATION OF THEORY OF PLANNED BEHAVIOR IN TEMANGGUNG, CENTRAL JAVA
}

\author{
Yovita Eka Ratna Kumala1), Setyo Sri Rahardjo²), \\ Endang Sutisna Sulaeman') \\ 1)Masters Program in Public Health, Universitas Sebelas Maret \\ ${ }^{2)}$ Faculty of Medicine, Universitas Sebelas Maret
}

\begin{abstract}
Background: Green tobacco sickness (GTS) is a type of nicotine poisoning that occurs while handling tobacco plants. Tobacco farmers are at especially high risk for developing this illness when their clothing becomes saturated from tobacco that is wet from rain or morning dew, or perspiration. The incidence of GTS reaches $63.7 \%$ in tobacco farmers. It can be prevented by using personal protection equipment (PPE). The purpose of this study was to analyze factors associated with the use of PPE in tobacco farmers in Temanggung, Central Java.

Subjects and Method: A cross sectional study was conducted at 20 villages in Temanggung, Central Java, from August to September 2019. A sample of 200 tobacco farmers was selected randomly. The dependent variable was the use of PPE. The independent variables were gender, education, attitude, subjective norm, intention, and perceived behavior control. The data were collected by questionnaire and analyzed by a multiple logistic regression.

Results: The use of PPE in tobacco farmers increased with male $(\mathrm{OR}=13.02 ; \mathrm{p}<0.001)$, education $\geq$ Senior high school $(\mathrm{OR}=12.74$; $\mathrm{p}<0.001)$, strong intention $(\mathrm{OR}=7.27 ; \mathrm{p}=$ 0.027), positive attitude $(\mathrm{OR}=4.73 ; \mathrm{p}=0.002)$, supportive subjective norm $(\mathrm{OR}=6.05 ; \mathrm{p}=$ $0.001)$, and strong perceived behavior control $(\mathrm{OR}=10.00 ; \mathrm{p}=0.003)$.

Conclusion: The use of PPE in tobacco farmers increases with male, education $\geq$ Senior high school, strong intention, positive attitude, supportive subjective norm, and strong perceived behavior control.
\end{abstract}

Keywords: personal protective equipment, tobacco farmers, theory of planned behavior

\section{Correspondence:}

Yovita Eka Ratna Kumala. Masters Program in Public Health, Universitas Sebelas Maret. Jl. Ir. Sutami 36A, Surakarta 57126, Central Java, Indonesia, 57126. Email: yovitakumala19@gmail.com. Mobile: 083867630850.

The $7^{\text {th }}$ International Conference on Public Health

Solo, Indonesia, November 18-19, $2020 \mid 165$ https://doi.org/10.26911/the7thicph.02.54 